\title{
The Role of Oxygen Free Radicals in Postasphyxia Cerebral Hypoperfusion in Newborn Lambs
}

\author{
ADAM A. ROSENBERG, ELIZABETH MURDAUGH, AND CARL W. WHITE \\ Department of Pediatrics, Sections of Neonatology and Pulmonology, University of Colorado School of Medicine, \\ Denver, Colorado 80262
}

\begin{abstract}
Previous work in a neonatal lamb model has demonstrated abnormalities in cerebral blood flow (CBF) and oxygen consumption $\left(\mathrm{CMRO}_{2}\right)$ after asphyxia. Immediately after resuscitation, there was a marked increase in $\mathrm{CBF}$ and a significant decrease in $\mathrm{CMRO}_{2}$ compared to control. During the late period after asphyxia (30 $\mathrm{min}$ to 4 h), both $\mathrm{CBF}$ and $\mathrm{CMRO}_{2}$ were significantly depressed. The same postasphyxia model $(n=16)$ was used to examine the hypothesis that generation of oxygen free radicals during cerebral reperfusion may be involved in the genesis of late postasphyxia hypoperfusion and depressed $\mathrm{CMRO}_{2}$. Before asphyxia, the animals were pretreated with either inactivated $(n=8)$ or active $(n=8)$ polyethylene glycol superoxide dismutase, $5000 \mathrm{U} / \mathrm{kg}$, and polyethylene glycol catalase, $100000 \mathrm{U} / \mathrm{kg}$. CBF (radioactive microspheres) and arterial and venous (superior sagittal sinus) blood gases and $\mathrm{O}_{2}$ contents were measured during control, and at $5 \mathrm{~min}, 1 \mathrm{~h}, 2 \mathrm{~h}$, and $4 \mathrm{~h}$ postasphyxia (PA). In the active enzyme group, 5 min postasphyxia $C B F$ was significantly increased compared to control: $211.5 \pm 28.0$ versus $78.6 \pm 11.4 \mathrm{ml} \cdot 100 \mathrm{~g}^{-1} \cdot \mathrm{min}^{-1}, \pm \mathrm{SEM}, p<0.005$. At $1 \mathrm{~h}(82.9 \pm 17.6), 2 \mathrm{~h}(62.3 \pm 5.5)$, and $4 \mathrm{~h}(78.9 \pm$ 12.2) PA, CBF did not differ significantly from control. More importantly, $\mathrm{CMRO}_{2}$ did not differ from control at any time PA. In the inactive enzyme group, both $\mathrm{CBF}$ and $\mathrm{CMRO}_{2}$ were depressed at 1,2 , and $4 \mathrm{~h} \mathrm{PA}$. These findings are consistent with a conclusion that damage by oxygen free radicals during postasphyxia cerebral reperfusion is important to the genesis of late PA blood flow and $\mathrm{O}_{2}$ metabolism abnormalities. To the extent that depressions in $\mathrm{CBF}$ and $\mathrm{CMRO}_{2}$ result in ongoing brain injury, agents that ameliorate these abnormalities may improve neurologic outcome. (Pediatr Res 26:215-219, 1989)
\end{abstract}

\section{Abbreviations}

CBF, cerebral blood flow

$\mathrm{CMRO}_{2}$ cerebral oxygen consumption

PA, postasphyxia

OFR, oxygen free radicals

PEG, polyethylene glycol

$\mathrm{CaO}_{2}$, arterial oxygen content

Work in a newborn lamb PA model has demonstrated abnormalities in PA, CBF and $\mathrm{CMRO}_{2}$ (1). In the immediate PA

Received February 27, 1989; accepted May 3, 1989.

Correspondence and reprints Adam A. Rosenberg, M.D., Container B195, University of Colorado Health Sciences Center, 4200 East 9th Avenue, Denver CO 80262. Supported by NIH Grant R01-HL36301. period, there was a state of reactive hyperemia. Despite this overperfusion, $\mathrm{CMRO}_{2}$ was depressed. In the late period after asphyxia (30 min to $4 \mathrm{~h}$ ) there was a significant depression of $\mathrm{CBF}$ and $\mathrm{CMRO}_{2}$. To the extent that these abnormalities of $\mathrm{CBF}$ and $\mathrm{CMRO}_{2}$ may contribute to brain injury, mechanisms involved in the genesis of cerebral hypoperfusion and decreased $\mathrm{CMRO}_{2}$ become important.

The postischemic production of OFR (e.g. superoxide ion, hydroxyl radical, and singlet oxygen) during reperfusion has been recognized to be important in the pathogenesis of injury in a variety of organ systems (2). In brain, OFR have been implicated in vascular injury seen with both acute hypertension and in a fluid percussion injury model (3-6). Furthermore, lipid peroxidation $(7)$ and production of the superoxide anion $(8,9)$ have been demonstrated in the brain after reperfusion from an ischemic insult. During ischemia, the brain concentration of hypoxanthine has been shown to increase (10-12) and the concentration of arachidonic acid to rise (13). When the tissue is reperfused, OFR can be generated from the oxidation of hypoxanthine (2) and as a by product of arachidonate metabolism through cyclooxygenase and lipoxygenase pathways $(14,15)$.

Using the newborn lamb PA model we sought to examine the hypothesis that generation of OFR during cerebral reperfusion plays a role in the genesis of late PA hypoperfusion and depressed $\mathrm{CMRO}_{2}$. The role of the OFR was studied by treating two groups of lambs before asphyxia with active or inactivated PEG-superoxide dismutase and PEG-catalase.

\section{MATERIALS AND METHODS}

Surgical procedure. A total of 16 newborn lambs were operated on under pentobarbital anesthesia on d 1-3 of life. Polyvinyl chloride catheters $(0.034$ in ID $\times 0.054$ in OD; Martech Medical Products, Lansdale, PA) were placed in the left ventricle via an axillary artery, the brachiocephalic artery via an axillary artery, the abdominal aorta via a femoral artery, the inferior vena cava via a femoral vein, and the posterior sagittal sinus proximal to the confluence of the veins. The sagittal sinus catheter was placed through a 1 inch in diameter burr hole in the midline proximal to the lambdoidal sutures. The catheters entering through the animal's extremities were protected in a pouch on the abdomen. The sagittal sinus catheter was cut, pinned, and sutured to the lamb's scalp. The animals were returned to their mothers and allowed a 24 -h recovery period before study. At that time, all lambs were standing and feeding normally. Previous work has demonstrated this is an adequate time interval to eliminate any pentobarbital effect on CBF (16).

Physiologic measurements. CBF was measured using the reference organ radiolabeled microsphere technique as previously described $(1,16-18)$. Withdrawal of the reference organ through the brachiocephalic artery catheter was into a counting vial by a 
precalibrated pump $\left(2.47 \mathrm{~mL} \cdot \mathrm{min}^{-1}\right.$; Harvard Apparatus, Dover, MA). After completion of the study, animals were killed with T-61 Euthanasia Solution (American Hoechst, Summerville, NJ), position of the catheters were checked, and the brain was removed. Brains were placed in formalin for $1 \mathrm{wk}$ and then divided into regions as previously described (1). Regions examined were brainstem (medulla and pons), right and left cerebellum, midbrain/diencephalon, frontal lobes, temporal lobes, occipital lobes, and parietal lobes. The radioactivity in each sample was determined using a three-channel $\gamma$-counter (Tracor Analytic, Des Plaines, IL) and regional blood flows calculated as previously described (16). Whole brain flow was calculated using the sum of the radioactive counts and weights for all regions except brainstem and cerebellum. Adequate central mixing of microspheres using a left ventricle injection site has been confirmed in the newborn lamb (17). All reference blood samples and tissue samples (except white matter) contained more than 400 microspheres (19). White matter had 200 to 400 microspheres.

Blood samples for $\mathrm{pH}, \mathrm{PCO}_{2}, \mathrm{PO}_{2}$, and $\mathrm{O}_{2}$ content were withdrawn anaerobically into heparinized Natelson glass pipettes from the brachiocephalic artery and sagittal sinus catheters. $\mathrm{PO}_{2}$, $\mathrm{PCO}_{2}$, and $\mathrm{pH}$ were measured at $39.5^{\circ} \mathrm{C}$ using the radiometer BMS3 MK2 (Radiometer, Copenhagen, Denmark). Blood Hb concentration expressed at $\mathrm{O}_{2}$ capacity and $\mathrm{O}_{2}$ saturation were measured colorimetrically in duplicate by a hemoximeter ( $\mathrm{Ra}-$ diometer), and $\mathrm{O}_{2}$ content was calculated as the product of $\mathrm{Hb}$ and $\mathrm{O}_{2}$ saturation. Blood pressure (referenced to the right atrium) and heart rate were continuously monitored in the abdominal aorta (Gould Instruments, Oxford, CA).

Experimental procedure. On the day of study, the animals were anesthetized with fentanyl $(20 \mu \mathrm{g} / \mathrm{kg}$ loading dose followed by $10 \mu \mathrm{g} / \mathrm{kg} / \mathrm{min}$ infusion), paralyzed with pancuronium $(0.1 \mathrm{mg} /$ $\mathrm{kg}$ ), intubated and ventilated with an infant ventilator (Bird, Co., Palm Springs, $\mathrm{CA}$ ) with a baseline gas mixture of $30-35 \% \quad \mathrm{O}_{2}$ and $65-70 \% \mathrm{~N}_{2}$ to provide a $\mathrm{PaO}_{2}$ of $10.7-16.0 \mathrm{KPa}$, and a baseline ventilator rate of $25-35$ breaths $/ \mathrm{min}$ to provide a $\mathrm{PaCO}_{2}$ of 4.4-5.1 KPa. Pancuronium and Fentanyl have been shown at the doses utilized in this study to have no effect on CBF and $\mathrm{CMRO}_{2}(20,21)$.

Measurements of $\mathrm{CBF}$ (radiolabeled microspheres), arterial and venous blood gases, and $\mathrm{O}_{2}$ contents were made during the control period. Eight animals then received $100000 \mathrm{U} / \mathrm{kg}$ of PEG-catalase and $5000 \mathrm{U} / \mathrm{kg}$ of PEG-superoxide dismutase intravenously, whereas eight received inactivated PEG enzymes. The enzyme doses were extrapolated from studies in rats using free and liposome entrapped enzymes to treat pulmonary and brain oxygen toxicity $(22-24)$. The animals were then subjected to a gradual asphyxial insult by altering inspired gas concentrations and ventilator rate as previously described $(1,21)$. In a stepwise fashion over a 30-min period, $\mathrm{PaO}_{2}$ was lowered to $2-$ $2.66 \mathrm{KPa}, \mathrm{CaO}_{2}$ was lowered to $0.67-1.12 \mathrm{mM}$, and $\mathrm{PaCO}_{2}$ was increased to $8-9.33 \mathrm{KPa}$. Over the first $60 \mathrm{~min}$ of asphyxia, heart rate and blood pressure were stable, but during the final 10-15 min the lambs became bradycardic (heart rate $<100$ beats $/ \mathrm{min}$ ) and hypotensive (mean arterial blood pressure, MAP 20-35 mm $\mathrm{Hg}$ ). The lambs were then returned to baseline ventilator settings and fractional inspired oxygen concentration. CBF (microspheres) arterial and venous blood gases, and $\mathrm{O}_{2}$ contents were measured at $5 \mathrm{~min}, 1 \mathrm{~h}, 2 \mathrm{~h}$, and $4 \mathrm{~h}$ after the termination of the insult. After the 4-h measurement, the animals were killed. Care and handling of animals was in accord with the published guidelines of the National Institutes of Health and has been approved by the Animal Care Committee of the University of Colorado.

Enzyme inactivation. PEG superoxide dismutase was irreversibly inactivated by its reaction with an excess of hydrogen peroxide that specifically oxidizes histidyl groups at the active site (25). After enzyme inactivation, excess $\mathrm{H}_{2} \mathrm{O}_{2}$ was removed by repeated dialysis. PEG-catalase was similarly inactivated in the presence of excess hydrogen peroxide and 3-amino-1,2,4- triazole that were then removed by dialysis $(26,27)$. After dialysis, each enzyme preparation was filtered $(0.2 \mu$ pore size $)$ to assure sterility.

Data analysis. $\mathrm{CMRO}_{2}$, cerebral $\mathrm{O}_{2}$ delivery, and fractional $\mathrm{O}_{2}$ extraction were calculated as previously described $(16,28)$. Comparisons were made for cerebral hemodynamic and other physiologic variables among control and the 4 PA determinations within each experimental group (active and inactive enzymes) using ANOVA with a repeated measures design. Regional flow data from the right and left sides of the brain were combined before analysis as no left-right differences were seen. Significance compared to control was determined at the $p<0.05$ level. CBF and $\mathrm{CMRO}_{2}$ data are also presented as percent of control measurements for both the active and inactive enzyme groups.

\section{RESULTS}

Changes in CBF over time are presented in Figure 1. The data are presented as percent of the control measurements. In both groups, CBF was markedly increased $5 \mathrm{~min}$ PA. In the active enzyme group CBF did not differ from control at $1 \mathrm{~h}, 2 \mathrm{~h}$, and $4 \mathrm{~h}$ PA whereas CBF was significantly decreased at these times in the inactive enzyme group. Regional flow data demonstrated the same pattern of changes as seen in whole brain for both groups (Table 1). In the active enzyme group no significant decreases in flow were present 1,2 , and $4 \mathrm{~h}$ PA, whereas flow was decreased in all regions at 1,2 , and $4 \mathrm{~h}$ PA in the inactive enzyme group. Figure 2 presents changes in $\mathrm{CMRO}_{2}$ over time in both groups with the data again presented as percent of the

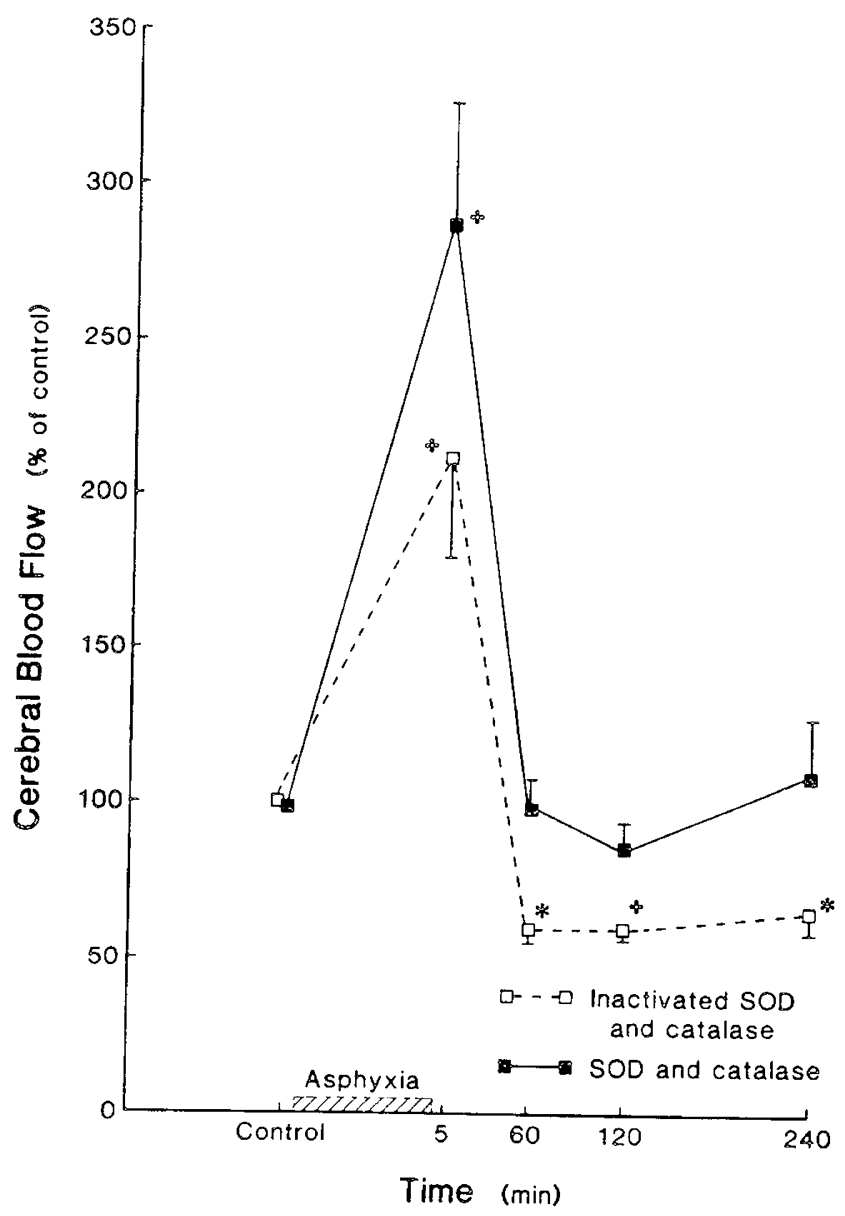

Fig. 1. CBF (\% of control) versus time after asphyxia for both active $(\square)$ and inactive $(\square)$ enzyme groups. Postasphyxia values are mean \pm SEM. Statistical analysis by repeated measures design ANOVA within each group. ${ }^{*} p<0.01$ from control within group; $\dagger p<0.005$ from control within group. 
Table 1. Regional brain flood flows*

\begin{tabular}{|c|c|c|c|c|c|}
\hline & Control & $5 \mathrm{~min} P A$ & $1 \mathrm{~h} \mathrm{PA}$ & $2 \mathrm{~h} \mathrm{PA}$ & $4 \mathrm{~h} \mathrm{PA}$ \\
\hline \multicolumn{6}{|l|}{ Inactive enzyme } \\
\hline Brainstem & $94.2 \pm 12.0$ & $266.2 \pm 41.7 \dagger$ & $54.4 \pm 5.3 \ddagger$ & $47.0 \pm 1.4 \dagger$ & $52.8 \pm 4.7 \ddagger$ \\
\hline Cerebellum & $100.7 \pm 11.8$ & $263.5 \pm 28.1 \dagger$ & $70.0 \pm 3.8 \div$ & $63.8 \pm 1.8 \dagger$ & $72.0 \pm 7.7 \S$ \\
\hline Midbrain/diencephalon & $98.7 \pm 11.6$ & $272.5 \pm 52.9 \dagger$ & $58.4 \pm 5.8 \ddagger$ & $53.5 \pm 2.3 \dagger$ & $59.8 \pm 5.4 \ddagger$ \\
\hline Frontal cortex & $86.7 \pm 8.0$ & $182.0 \pm 20.4 \dagger$ & $48.0 \pm 2.7 \dagger$ & $47.2 \pm 2.5 \dagger$ & $50.3 \pm 3.5 \ddagger$ \\
\hline Temporal cortex & $66.7 \pm 7.3$ & $174.2 \pm 23.1 \dagger$ & $35.0 \pm 1.9 \dagger$ & $34.7 \pm 2.0 \dagger$ & $39.0 \pm 3.1 \ddagger$ \\
\hline Occipital cortex & $92.3 \pm 8.2$ & $185.2 \pm 19.2 \dagger$ & $56.0 \pm 3.6 \ddagger$ & $55.2 \pm 3.4 \ddagger$ & $58.5 \pm 4.0 \ddagger$ \\
\hline Parietal cortex & $89.8 \pm 7.9$ & $183.2 \pm 20.4 \dagger$ & $53.2 \pm 3.6 \ddagger$ & $52.5 \pm 2.6 \dagger$ & $57.0 \pm 3.2 \ddagger$ \\
\hline \multicolumn{6}{|l|}{ Active enzyme } \\
\hline Brainstem & $72.5 \pm 12.2$ & $291.3 \pm 52.0 \dagger$ & $102.9 \pm 18.6$ & $61.5 \pm 7.4$ & $84.3 \pm 10.3$ \\
\hline Cerebellum & $85.6 \pm 12.4$ & $328.0 \pm 41.5 \dagger$ & $105.4 \pm 15.2$ & $90.8 \pm 10.3$ & $102.8 \pm 10.9$ \\
\hline Midbrain/diencephalon & $79.4 \pm 11.5$ & $307.1 \pm 58.2 \dagger$ & $100.9 \pm 15.6$ & $72.8 \pm 8.3$ & $85.3 \pm 16.6$ \\
\hline Frontal cortex & $77.5 \pm 11.1$ & $211.8 \pm 27.6 \dagger$ & $75.3 \pm 14.6$ & $61.5 \pm 5.2$ & $80.7 \pm 8.7$ \\
\hline Temporal cortex & $58.6 \pm 7.1$ & $179.9 \pm 27.8 \dagger$ & $62.1 \pm 15.7$ & $48.9 \pm 4.6$ & $63.3 \pm 7.4$ \\
\hline Occipital cortex & $85.2 \pm 12.5$ & $218.6 \pm 30.3 \dagger$ & $86.6 \pm 18.3$ & $69.4 \pm 5.8$ & $91.2 \pm 12.0$ \\
\hline Parietal cortex & $81.3 \pm 10.2$ & $211.0 \pm 27.5 \dagger$ & $83.2 \pm 17.4$ & $65.5 \pm 5.6$ & $84.3 \pm 11.0$ \\
\hline
\end{tabular}

* All values are mean $\pm \mathrm{SEM}$ in $\mathrm{ml} \cdot 100 \mathrm{~g}^{-1} \cdot \mathrm{min}^{-1}$.

$\dagger p<0.005$.

$\ddagger p<0.01$.

$\S p<0.05$.

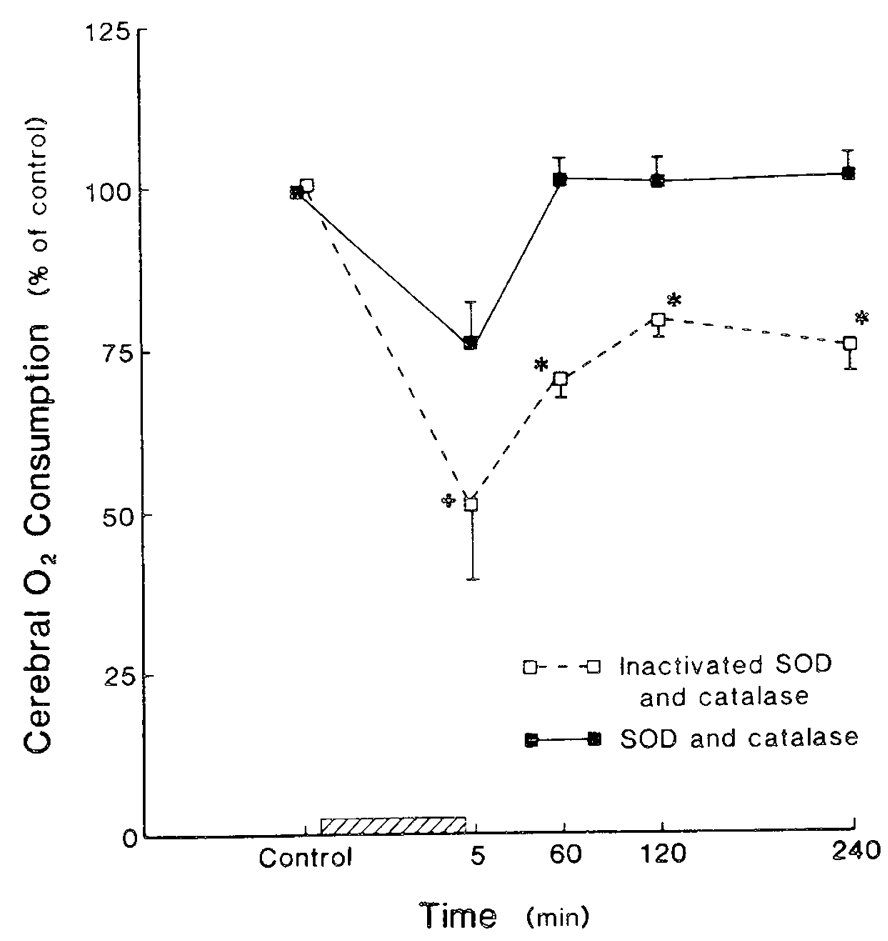

Fig. 2. $\mathrm{CMRO}_{2}$ (\% of control) versus time after asphyxia for both

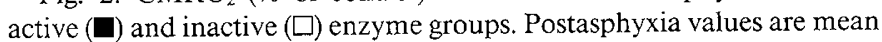
\pm SEM. Statistical analysis by repeated measures design ANOVA within each group. ${ }^{*} p<0.05$ from control within group; $\nmid p<0.01$ from control within group.

control measurements. With inactive enzyme, $\mathrm{CMRO}_{2}$ was depressed below control at all times PA, whereas $\mathrm{CMRO}_{2}$ did not differ from control in the active enzyme group. Other cerebral hemodynamic variables for both the active and inactive enzyme groups are presented in Table 2. Cerebral $\mathrm{O}_{2}$ delivery, the product of $\mathrm{CBF} \times \mathrm{CaO}_{2}$, mirrors changes in $\mathrm{CBF}$. In both groups, oxygen delivery is significantly increased compared to control 5 min PA. In the active enzyme group, oxygen delivery does not differ from control at 1,2 , and $4 \mathrm{~h}$ PA whereas significant decreases from control are present at these times in the inactive enzyme group. Fractional $\mathrm{O}_{2}$ extraction, the relationship between $\mathrm{O}_{2}$ uptake and delivery, is significantly decreased $5 \mathrm{~min}$ PA, and no different from control at 1, 2, and $4 \mathrm{~h} \mathrm{PA}$ in both groups. Tables 3 and 4 present physiologic variables for the inactive and active enzyme groups. In each group, the only differences over time were an increase in $\mathrm{PaO}_{2} 5$ min $\mathrm{PA}$ and a decrease in $\mathrm{pH}$ from control at $5 \mathrm{~min}, 1 \mathrm{~h}$, and $2 \mathrm{~h}$ PA. In neither animal group did variables known to influence cerebral hemodynamic data; $\mathrm{PaCO}_{2}, \mathrm{CaO}_{2}$, and mean arterial blood pressure change over time.

\section{DISCUSSION}

Although Myer's (29) elegant studies have detailed clinical and pathologic changes seen with neonatal asphyxia and emphasized the role of hypoxic ischemic insults in brain damage, little information is available in a neonatal model describing mechanisms of damage incurred during the PA period. The importance of postischemic events has been emphasized by work in several ischemia models. Neuronal damage in the neocortex and hippocampus of rats exposed to four-vessel occlusion worsened for hours to days after relatively brief forebrain ischemia (30). Furthermore, CNS damage has been minimized by posthypoxic ischemic pharmacologic interventions designed to improve $\mathrm{CBF}$ (31-33). The current study demonstrated that OFR scavenging enzymes prevent PA late hypoperfusion and depressed $\mathrm{CMRO}_{2}$ in the newborn lamb. These findings are consistent with the hypothesis that damage by OFR during PA reperfusion may be important to the genesis of PA abnormalities in CBF and $\mathrm{CMRO}_{2}$. The newborn lamb PA model has been used previously to study physiologic and metabolic changes after asphyxia $(1,21$, 34). However, pathologic studies have not yet been performed to assess brain parenchymal or vascular injury in the model. Nonetheless, to the extent that depressions of $\mathrm{CBF}$ and $\mathrm{CMRO}_{2}$ might contribute to and/or reflect PA brain injury, these findings may be important.

There are several mechanisms to consider that allow OFR scavengers to improve PA CBF and $\mathrm{CMRO}_{2}$. The late hypoperfusion seen in the control lambs may be the result of cerebral edema impinging on capillaries impairing blood flow (35). OFR have been shown to increase endothelial permeability to macromolecules (36), however, previous work in the newborn lamb has failed to demonstrate cerebral edema during the period of late hypoperfusion (21). Alternatively, increased production of vasoconstrictor arachidonate metabolites (e.g. thromboxane $\mathrm{A}_{2}$ or leukotrienes) potentiated by $\mathrm{O}_{2}$ metabolites may be etiologic 
Table 2. Cerebral hemodynamic variables*

\begin{tabular}{cccccc}
\hline & Control & $5 \mathrm{~min} \mathrm{PA}$ & $1 \mathrm{~h} \mathrm{PA}$ & $2 \mathrm{~h}$ PA & $4 \mathrm{~h} \mathrm{PA}$ \\
\hline Inactive enzyme & & & & & \\
OD $\left(\mu \mathrm{M} \cdot 100 \mathrm{~g}^{-1} \cdot \mathrm{min}^{-1}\right)$ & $611 \pm 64$ & $1359 \pm 187 \dagger$ & $380 \pm 49 \dagger$ & $384 \pm 21 \dagger$ & $394 \pm 17 \pm$ \\
Fractional $\mathrm{O}_{2}$ extraction & $0.43 \pm 0.04$ & $0.07 \pm 0.01 \dagger$ & $0.51 \pm 0.05$ & $0.53 \pm 0.03$ & $0.48 \pm 0.03$ \\
& & & & \\
Active enzyme & & & & $513 \pm 52$ & $596 \pm 100$ \\
$\mathrm{OD}\left(\mu \mathrm{M} \cdot 100 \mathrm{~g}^{-1} \cdot \mathrm{min}^{-1}\right)$ & $600 \pm 86$ & $1650 \pm 238 \dagger$ & $667 \pm 133$ & 513 \\
Fractional $\mathrm{O}_{2}$ extraction & $0.40 \pm 0.05$ & $0.13 \pm 0.04 \ddagger$ & $0.40 \pm 0.06$ & $0.42 \pm 0.03$ & $0.40 \pm 0.05$ \\
\hline
\end{tabular}

* All values are mean $\pm \mathrm{SEM}$. OD, cerebral oxygen delivery.

$\dagger p<0.005$.

$\ddagger p<0.01$.

Table 3. Physiologic variables-inactivated SOD/CAT*

\begin{tabular}{|c|c|c|c|c|c|}
\hline & Control & $5 \min P A$ & $1 \mathrm{~h}$ PA & $2 \mathrm{~h} \mathrm{PA}$ & $4 \mathrm{~h} \mathrm{PA}$ \\
\hline $\mathrm{PaO}_{2}(\mathrm{kPa})$ & $15.3 \pm 1.0$ & $19.9 \pm 0.8 \dagger$ & $15.0 \pm 1.1$ & $14.4 \pm 0.9$ & $14.5 \pm 0.7$ \\
\hline $\mathrm{PaCO}_{2}(\mathrm{kPa})$ & $4.47 \pm 0.13$ & $3.87 \pm 0.15$ & $4.20 \pm 0.17$ & $4.53 \pm 0.16$ & $4.40 \pm 0.19$ \\
\hline $\mathrm{pH}$ & $7.47 \pm 0.02$ & $6.95 \pm 0.03 \ddagger$ & $7.16 \pm 0.05 \dagger$ & $7.26 \pm 0.05 \dagger$ & $7.35 \pm 0.03$ \\
\hline $\mathrm{CaO}_{2}(\mathrm{mM})$ & $6.79 \pm 0.67$ & $7.28 \pm 0.80$ & $7.10 \pm 0.63$ & $7.28 \pm 0.58$ & $6.92 \pm 0.49$ \\
\hline $\mathrm{MAP}(\mathrm{mm} \mathrm{Hg})$ & $83 \pm 7$ & $98 \pm 5$ & $86 \pm 3$ & $83 \pm 4$ & $73 \pm 2$ \\
\hline $\mathrm{HR}\left(\mathrm{bpm}^{-1}\right)$ & $235 \pm 21$ & $250 \pm 0$ & $275 \pm 19$ & $281 \pm 22$ & $250 \pm 17$ \\
\hline
\end{tabular}

* All values are mean \pm SEM. MAP, mean arterial blood pressure; HR, heart rate, $1 \mathrm{~mm} \mathrm{Hg}, 0.1333 \mathrm{kPa}$.

$\dagger p<0.05$ from control.

$\ddagger p<0.01$ from control.

Table 4. Physiologic variables-SOD/CAT*

\begin{tabular}{|c|c|c|c|c|c|}
\hline & Control & $5 \mathrm{~min} P A$ & $1 \mathrm{~h} \mathrm{PA}$ & $2 \mathrm{~h}$ PA & $4 \mathrm{~h}$ PA \\
\hline $\mathrm{PaO}_{2}(\mathrm{kPa})$ & $15.6 \pm 0.7$ & $19.1 \pm 0.8 \dagger$ & $15.3 \pm 0.6$ & $14.5 \pm 0.8$ & $14.4 \pm 0.8$ \\
\hline $\mathrm{PaCO}_{2}(\mathrm{kPa})$ & $4.67 \pm 0.24$ & $4.00 \pm 0.33$ & $4.48 \pm 0.36$ & $4.67 \pm 0.20$ & $4.75 \pm 0.23$ \\
\hline $\mathrm{pH}$ & $7.43 \pm 0.03$ & $6.94 \pm 0.05 \ddagger$ & $7.18 \pm 0.04 \dagger$ & $7.26 \pm 0.03 \dagger$ & $7.30 \pm 0.03$ \\
\hline $\mathrm{CaO}_{2}(\mathrm{mM})$ & $7.68 \pm 0.22$ & $7.68 \pm 0.22$ & $8.17 \pm 0.27$ & $8.26 \pm 0.27$ & $7.59 \pm 0.31$ \\
\hline MAP (mm Hg) & $80 \pm 5$ & $88 \pm 5$ & $81 \pm 5$ & $79 \pm 6$ & $69 \pm 5$ \\
\hline $\mathrm{HR}\left(\mathrm{bpm}^{-1}\right)$ & $250 \pm 11$ & $254 \pm 15$ & $276 \pm 8$ & $288 \pm 9$ & $293 \pm 19$ \\
\hline
\end{tabular}

* All values are mean \pm SEM. MAP, mean arterial blood pressure; HR, heart rate; $1 \mathrm{~mm} \mathrm{Hg}, 0.1333 \mathrm{kPa}$

$\dagger p<0.05$ from control.

$\ddagger p<0.01$ from control.

to late hypoperfusion $(37,38)$. The other attractive explanation for decreased CBF at $1-4 \mathrm{~h}$ PA is that OFR damage cerebral vessels causing a vasoconstricted state. Vascular injury due to OFR has been seen in other brain injury models (3-6).

The decrease in $\mathrm{CMRO}_{2}$ seen in the control lambs could be the result of impaired mitochondrial function as OFR have been shown to inhibit mitochondrial respiration (39). In the newborn lamb PA model, inhibition of mitochondrial respiration is present 5 min PA, but recovery of function toward baseline is seen by $2 \mathrm{~h}$ PA (34). Thus the improved $\mathrm{CMRO}_{2}$ after treatment with superoxide dismutase and catalase at $5 \mathrm{~min}$ PA may be due to improved mitochendrial function, but another explanation must be sought for the increased $\mathrm{CMRO}_{2}$ at $1-4 \mathrm{~h}$ PA. Alternatively, the higher $\mathrm{CMRO}_{2}$ in the treated animals $1-4 \mathrm{~h}$ PA may simply be the result of the increased $\mathrm{CBF}$. This concept would be supported by the normal relationship between $\mathrm{CBF}$ and $\mathrm{CMRO}_{2}$, the fractional $\mathrm{O}_{2}$ extraction, 1,2 , and $4 \mathrm{~h} \mathrm{PA}$ in both active and inactive enzyme groups.

The data in the current study are consistent with work in other newborn as well as adult postischemia/asphyxia models. In adult dogs the combination of superoxide dismutase and deferoxamine (to decrease OFR production) improved post cardiac arrest CBF, $\mathrm{CMRO}_{2}$ and recovery of somatosensory evoked potentials (40). In an exteriorized fetal sheep model, the combination of OFR scavengers and a calcium channel blocker also resulted in improved PA CBF and better recovery of somatosensory evoked potentials (41). However, in the latter study the role of of OFR scavengers alone in improved $\mathrm{CBF}$ and neurologic function cannot be confirmed because calcium channel blockers alone have been shown to improve postischemic CBF (31).

PEG superoxide dismutase and catalase were chosen for this study because the PEG linkage blocks renal clearance of the enzymes allowing active enzyme to circulate for long periods of time. Modification by PEG increases the circulating $t_{1 / 2}$ from 6 min to $30-40 \mathrm{~h}$ in the rat (42). The inert characteristics of PEG also reduce the immunogenicity of the enzymes and inhibits hydrolysis of protease sensitive proteins such as catalase (43). For these reasons a continuous infusion was not necessary. Furthermore, conjugation of the enzyme to PEG enhances enzyme uptake by cultured endothelial cells (44). The combination of the two enzymes was selected to scavenge both the superoxide ion as well as hydrogen peroxide. Both superoxide and hydrogen peroxide are implicated in the formation of the most reactive and toxic OFR, hydroxyl radical, through the Haber-Weiss reaction. It is the hydroxyl radical in particular that has been implicated as the damaging species in other brain injury models (3-6). Finally, it is worth noting that PEG has been shown itself to be a hydroxyl radical scavenger (22). For that reason, inactivated PEG enzymes were used in the control group. No independent effect of PEG was evident in the current study as the inactive enzyme group demonstrated similar PA changes in $\mathrm{CBF}$ and $\mathrm{CMRO}_{2}$ as historic controls (1).

Another important issue is site of action of the superoxide dismutase and catalase and the source of production of OFR. Entry into the CNS of high mol wt enzymes would require a disruption in the blood brain barrier. Such may be the case PA. 
Another possibility is that the enzymes act locally at the vessel wall. This seems likely because it has been demonstrated the cerebral vessel walls can produce OFR from arachidonate metabolism (45), and that the enzyme xanthine dehydrogenase is known to be present on the surface of brain endothelial cells (46). This enzyme is converted to xanthine oxidase during ischemia and with reperfusion metabolizes hypoxanthine and oxygen releasing OFR. It is also possible that the enzymes operate at non-central nervous system sites. Circulating xanthine oxidase and its substrate have been demonstrated in humans with adult respiratory distress syndrome (47). These circulating OFR could be the source of tissue injury with the PEG enzymes offering protection by scavenging these circulating OFR. The enzymes could also indirectly improve PA cerebral perfusion by preventing myocardial injury and improving PA cardiac output. This seems unlikely because previous work on this model (1) (Rosenberg AA, unpublished observations) did not demonstrate decreased cardiac output compared to control at 1,2 , and $4 \mathrm{~h}$ PA.

In conclusion, the present study has shown an improvement in postasphyxia $\mathrm{CBF}$ and $\mathrm{CMRO}_{2}$ in the newborn lamb after treatment with OFR scavenging enzymes. To the extent that these abnormalities in $\mathrm{CBF}$ and $\mathrm{CMRO}_{2}$ are important to the genesis of brain injury, agents that correct these abnormalities may be of use in this clinical setting.

Acknowledgments. The authors thank Karin More, Karen Trembler, I-Da Fan, Y-Ching Fan Cheng, and Lee Hatten for technical assistance, and Nancy Briggs for preparation of the manuscript. The authors are also indebted to Enzon, Inc., Plainfield, NJ for generously supplying PEG-superoxide dismutase and catalase.

\section{REFERENCES}

1. Rosenberg AA 1986 Cerebral blood flow and $\mathrm{O}_{2}$ metabolism after asphyxia in neonatal lambs. Pediatr Res 20:778-782

2. McCord JM 1985 Oxygen-derived free radicals in post ischemic tissue injury. N Engl J Med 312:159-163

3. Kontos HA 1985 Oxygen radicals in cerebral vascular injury. Circ Res 57:508516

4. Kontos HA, Wei EP, Christman CW, Levasseur JE, Povlishock JT, Ellis, EF 1983 Free oxygen radicals in cerebral vascular responses. Physiologist 26:165-169

5. Wei EP, Dietrich WD, Povlishock JT, Naveri RM, Kontos HA 1980 Functional, morphological, and metabolic abnormalities of the cerebral microcirculation after concussive brain injury in cats. Circ Res 46:37-47

6. Wei EP, Kontos HA, Dietrich WD, Povlishock JT, Ellis EF 1981 Inhibition by free radical scavengers and by cyclooxygenase inhibitors of pial arteriolar abnormalities from concussive brain injury in cats. Circ Res 48:95-103

7. Watson WD, Busto R, Goldberg WJ, Santiso M, Yoshida S, Ginsberg MD 1984 Lipid peroxidation in vivo induced by reversible global ischemia in rat brain.J Neurochem 42:268-74

8. Armstead WM, Mirro R, Busija DW, Leffler CW 1988 Postischemic generation of superoxide anion by newborn pig brain. Am J Physiol 255:H401-H403

9. Pourcyrous M, Leffler C, Busija DW 1989 Superoxide anion generation during asphyxia in newborn pigs. FASAB 3:A241

10. Kleihues P, Kobayashi K, Hossmann KA 1974 Purine nucleotide metabolism in the cat brain after one hour of complete ischemia. J Neurochem 23:417425

11. Winn HR, Rubio H, Berne RM 1979 Brain adenosine production in the rat during 60 seconds of ischemia. Circ Res 45:486-492

12. Thiringer K, Blomstrand S, Hrbek A, Karlsson K, Kjellmer I 1982 Cerebra arterio-venous difference for hypoxanthine and lactate during graded asphyxia in the fetal lamb. Brain Res 239:107-117

13. Bazan NG 1970 Effects of ischemia and electroconvulsive shock on free fatty acid pool in the brain. Biochem Biophys Acta 218:1-10

14. Yoshida S, Inoh S, Asano T, Sano K, Kubota M, Shimazaki H, Veta N 1980 Effect of transient ischemia on free fatty acids and phospholipids in the gerbil brain. J Neurosurg 53:323-331

15. Pourcyrous M, Leffler C, Busija DW 1988 Postasphyxial increases in prostanoids in cerebrospinal fluid of piglets. Pediatr Res 24:229-232

16. Rosenberg AA, Jones MD, Traystman RJ, Simmons MA, Molteni RA 1982 Response of cerebral blood flow to changes in $\mathrm{PCO}_{2}$ in fetal, newborn and adult sheep. Am J Physiol 242:H862-H866

17. Rosenberg AA, Jones MD, Koehler RC, Traystman RJ, Lister G 1983 Precautions for measuring blood flow during anemia with the microsphere technique. Am J Physiol 244:H308-H311
18. Heymann MA, Payne BD, Hoffman JIE, Rudolph AM 1977 Blood flow measurements with radionuclide-labelled particles. Prog Cardiovasc Dis 20:55-79

19. Buckberg GD, Luck JL, Payne B, Hoffman JIE, Archie J, Fixler DE 1971 Some sources of error in measuring regional blood flow with radioactive microspheres. J Appl Physiol 31:598-604

20. Belik J, Wagerle LC, Delivoria-Papadopoulos M 1984 Cerebral blood flow and metabolism following pancuronium bromide in newborn lambs. Pediatr Res 18:1305-1308

21. Rosenberg AA 1988 Regulation of cerebral blood flow after asphyxia in neonatal lambs. Stroke 19:239-244

22. White CW, Jackson JH, Abuchowski A, Kazo GM, Mimmack RF, Berger EM, Freeman BA, McCord JM, Repine JE 1989 Polyethylene glycol-attached superoxide dismutase and catalase treatment decreases pulmonary oxygen toxicity in rats. J Appl Physiol. 66:584-590

23. Turrens JF, Crapo JD, Freeman BA 1984 Protection against oxygen toxicity by intravenous injection of liposome-entrapped catalase and superoxide dismutase. J Clin Invest 73:87-95

24. Yusa T, Crapo JD, Freeman BA 1984 Liposome-mediated augmentation of brain SOD and catalase inhibits $\mathrm{CNS} \mathrm{O}_{2}$ toxicity. J Appl Physiol 57:16741681

25. Hodgson EK, Fridovich I 1975. The interaction of bovine erythrocyte superoxide dismutase with hydrogen peroxide: inactivation of the enzyme Biochemistry 14:5294-5299

26. Feinstein RN, Berliner S, Green FO 1958. Mechanism of inhibition of catalase by 3-amino-1,2,4-triazole. Arch Biochem Biophys 76:32-44

27. Margoliash E, Novogrodsky A, Shejter A 1960. Irreversible reaction of 3amino-1,2,4-triazole and related inhibitors with protein of catalase. J Biol Chem 74:339-348

28. Jones MD, Traystman RJ, Simmons MA, Molteni RA 1981 The effects of changes in arterial $\mathrm{O}_{2}$ content in cerebral blood flow in the lamb. Am J Physiol 240:H209-H215

29. Myers RE 1977 Experimental models of perinatal brain damage: relevance to human pathology. In: Gluck L (ed) Intrauterine Asphyxia and the Developing Fetal Brain. Yearbook Medical Publishers, Chicago, pp 37-97

30. Pulsinelli W, Brierly J, Plum F 1982 Temporal profile of neuronal damage in a model of transient forebrain ischemia. Ann Neurol 11:491-498

31. Steen PA, Newberg LA, Milde JH, Michenfelder JD 1983 Nimodipine improves cerebral blood flow and neurologic recovery after complete cerebral ischemia in the dog. J Cereb Blood Flow Metab 3:38-43

32. Gaudet RJ, Levine L 1979 Transient cerebral ischemia and brain prostaglandins. Biochem Biophys Res Commun 86:893-901

33. Hallenbeck JM, Furlow TW 1979 Prostaglandin $I_{2}$ and indomethacin prevent impairment of post ischemic brain perfusion in the dog. Stroke 10:629-636

34. Rosenberg AA, Parks JK, Murdaugh E, Parker WD 1989 Mitochondrial function after asphyxia in the newborn lamb. Stroke 20:674-679

35. Miller CL, Lampard DG, Alexander K, Brown WA 1980 Local cerebral blood flow following transient cerebral ischemia. 1. Onset of impaired reperfusion within the first hour following global ischemia. Stroke 11:534-541

36. Shasby DM, Lind SE, Shasby SS, Goldsmith JC, Hunninghake GW 1985. Reversible oxidant induced increases in albumin transfer across cultured endothelium: alterations in cell shape and calcium homeostasis. Blood 65:605-614

37. Tate RM, Morris HG, Schroeder WR, Repine JE 1984 Oxygen metabolites stimulate thromboxane production and vasoconstriction in isolated saline perfused rat lungs. J Clin Invest 74:608-613

38. Lands WE 1985 Interactions of lipid hydroperoxides with eicosanoid biosynthesis. J Free Radicals Biol Med 1:97-101

39. Hillered L, Ernster L 1983 Respiratory activity of isolated rat brain mitochondria following in vitro exposure to oxygen radicals. $J$ Cereb Blood Flow Metab 3:207-214

40. Cerchiari EL, Hoel TM, Safar P, Sclabassi RJ 1987 Protective effects of combined superoxide dismutase and deferoxamine on recovery of cerebral blood flow and function after cardiac arrest in dogs. Stroke 18:869-878

41. Thiringer K, Hrbek A, Karlsson K, Rosen KG, Kjellmer I 1987 Postasphyxial cerebral survival in newborn sheep after treatment with oxygen free radical scavengers and a calcium antagonist. Pediatr Res 22:62-66

42. Pyatak PS, Abuchowski A, Davis FF 1980 Preparation of a polyethylene glycol: superoxide dismutase adduct, and an examination of its blood circulating life and anti-inflammatory activity. Res Commun Chem Pathol Pharmacol 29:113-127

43. Abuchowski A, McCoy JR, Palczuk N, Van Es T, Davis FF 1977 Effect of covalent attachment of polyethylene glycol on immunogenicity and circulating life of bovine liver catalase. J Biol Chem 252:3582-3586

44. Beckman JS, Minor RL, White CW, Repine JE, Rosen GM, Freeman BA 1988 Superoxide dismutase and catalase conjugated to polyethylene glycol increases endothelial enzyme activity and oxidant resistance. J Biol Chem 263:6884-6892

45. Levasseur JE, Kontos HA, Ellis EF 1985 Reduction in cerebral arteriolar oxygen consumption by arachidonate. Am J Physiol 248:H534-H539

46. Betz AL 1985 Identification of hypoxanthine transport and xanthine oxidase activity in brain capillaries. J Neurochem 44:574-579

47. Grum CM, Ragsdale RA, Ketai LH, Simon RH 1987 Plasma xanthine oxidase activity in patients with adult respiratory distress syndrome. J Crit Care $2: 22-26$ 